\title{
The Aggressive Cholesterol Therapy to Inhibit Vein Graft Events trial: To continue or not? How to answer the question
} \author{
Robert M. Sade, MD ${ }^{\mathrm{d}}$ \\ From the a Division of Thoracic Surgery, Department of Surgery, The Ohio State University, Columbus, Ohio; \\ ${ }^{\mathrm{b}}$ Section of General Thoracic Surgery, Duke University Medical Center, Durham, NC; 'Division of \\ Cardiovascular Surgery, Toronto General Hospital and Toronto General Research Institute, University Health \\ Network, Toronto, Ontario, Canada; and ${ }^{\mathrm{d} D i v i s i o n}$ of Cardiothoracic Surgery, Department of Surgery, Institute \\ of Human Values in Health Care, Medical University of South Carolina, Charleston, SC. \\ Disclosures: Authors have nothing to disclose with regard to commercial support. \\ Received for publication Sept 17, 2018; accepted for publication Sept 18, 2018; available ahead of print Nov 2, \\ 2018. \\ Address for reprints: Susan D. Moffatt-Bruce, MD, PhD, MBA, Division of Thoracic Surgery, Department of \\ Surgery, 168 Doan Hall, 410 W 10th Ave, Columbus, OH 43210 (E-mail: Susan.moffatt-bruce@ osumc.edu). \\ J Thorac Cardiovasc Surg 2019;157:164-5 \\ $0022-5223 / \$ 36.00$ \\ Copyright $\odot 2018$ by The American Association for Thoracic Surgery \\ https://doi.org/10.1016/j.jtcvs.2018.09.066
}

Susan D. Moffatt-Bruce, MD, PhD, MBA, ${ }^{a}$ Thomas A. D'Amico, MD, ${ }^{\mathrm{b}}$ Richard D. Weisel, $\mathrm{MD},{ }^{\mathrm{c}}$ and
In this month's issue of the Journal, Kulik and colleagues ${ }^{1}$ report the results of the Aggressive Cholesterol Therapy to Inhibit Vein Graft Events (ACTIVE) trial. In a pilot multicenter double-randomized trial, 173 patients who had undergone coronary artery bypass grafting (CABG) with saphenous vein graft were randomly allocated to receive atorvastatin either $10 \mathrm{mg}$ (low intensity) or $80 \mathrm{mg}$ (high intensity) daily for 1 year. The primary outcome was saphenous vein graft occlusion at 1 year; this outcome did not differ between the two groups, even though the higher dose therapy significantly lowered the low-density lipoprotein cholesterol levels after surgery by $26.1 \%{ }^{1}$ Oversight was provided by individual site institutional review boards, the US Food and Drug Administration, and Health Canada. A data and safety monitoring board was not explicitly mentioned in the publication. The trial was stopped prematurely in 2016 and did not reach the target of 200 subjects because of recruitment difficulties and changes in the 2013 American College of Cardiology and American Heart Association guideline regarding statin use. $^{2,3}$ The guideline changes included a class 1 , grade A recommendation to place all patients undergoing CABG on a high-dose statin regimen. ${ }^{3}$

Important questions are raised by the ACTIVE study as to when a trial should be terminated prematurely. Previously, 2 trials of induction therapy closed prematurely when several studies (International Adjuvant Lung Cancer Trial, Cancer and Leukemia Group B 9633) demonstrated an advantage relative to adjuvant chemotherapy after surgery. ${ }^{4,5}$ The investigators believed that induction therapy trials could no longer ethically accrue patients to the surgery-only arm, because adjuvant chemotherapy had been demonstrated to confer a significant survival benefit. ${ }^{4,5}$ Recent recommendations have included providing better

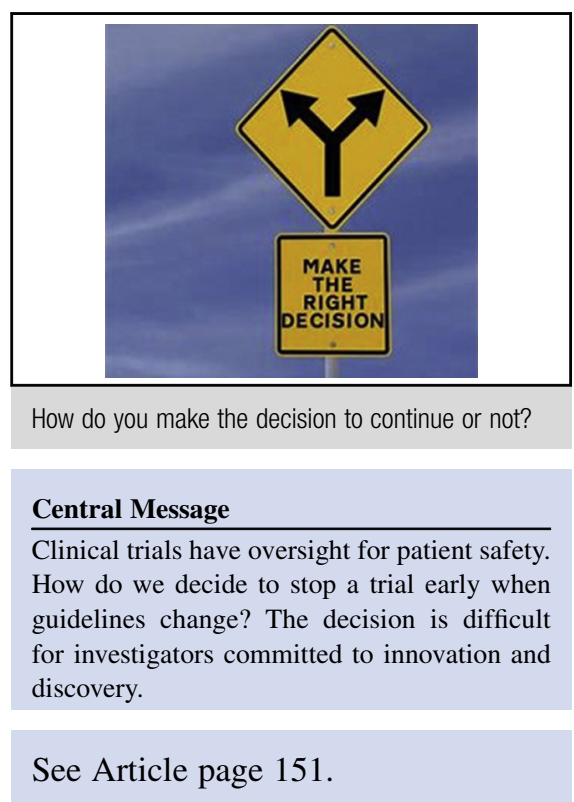

guidance for data and safety monitoring boards in trials involving cardiovascular disease and introducing independent advisory bodies, training modules, and mentorship programs to provide unbiased, consistent, and integrity-based oversight. ${ }^{6,7}$ The institutional review boards, US Food and Drug Administration, and Health Canada provided oversight for the ACTIVE clinical trial, but they may not have been aware that the recommendations for statin therapy changed during the trial because no adverse events occurred. Is it the responsibility of the investigators, the data and safety monitoring boards, the institutional review boards, or oversight agencies to review changing guidelines while a trial is active? We know of no regulations or guidelines that address that question. Another important question is whether a trial should be discontinued on the basis of changes in clinical guidelines that are updated with peer-reviewed iterations. Are guidelines merely recommendations, or should they be rigidly applied to ongoing clinical trials? Clinical adoption of the 2013 American College of Cardiology and American Heart Association guidelines was only modest, despite an impressive projected decrease in cardiovascular disease. ${ }^{8,9}$ The argument could also be made that early trial closure "wastes" the contributions of patients. ${ }^{10}$ 
The Belmont Report established 3 basic ethical principles to guide clinical research: respect for persons, beneficence, and justice. ${ }^{11}$ Grade A recommendations have a "high certainty based on evidence that the net benefit is substantial" and seem to rigorously uphold research ethics, but important questions remain. ${ }^{12}$ The ACTIVE investigators have not disregarded their responsibilities, but blurred lines of recommendations and guidelines as they apply to clinical research do not sufficiently clarify the lines of responsibility for making important research decisions.

\section{References}

1. Kulik A, Abreu AM, Boronat V, Ruel M. Intensive versus moderate statin therapy and early graft occlusion after coronary bypass surgery: the Aggressive Cholesterol Therapy to Inhibit Vein Graft Events randomized clinical trial. J Thorac Cardiovasc Surg. 2019;157:151-61.e1.

2. Kulik A, Ruel M, Jneid H, Ferguson TB, Hiratzka LF, Ikonomidis JS, et al; American Heart Association Council on Cardiovascular Surgery and Anesthesia. Secondary prevention after coronary artery bypass graft surgery: a scientific statement from the American Heart Association. Circulation. 2015;131:927-64.

3. Stone NJ, Robinson JG, Lichtenstein AH, Bairey Merz CN, Blum CB, Eckel RH, et al; American College of Cardiology/American Heart Association Task Force on Practice Guidelines. 2013 ACC/AHA guideline on the treatment of blood cholesterol to reduce atherosclerotic cardiovascular risk in adults: a report of the American College of Cardiology/American Heart Association task force on practice guidelines. Circulation. 2014;129(25 Suppl 2):S1-45. Erratum in: Circulation. 2014;129(25 Suppl 2):S46-8.

4. Pisters KMW, Vallières E, Crowley JJ, Franklin WA, Bunn PA Jr, Ginsberg RJ, et al. Surgery with or without preoperative paclitaxel and carboplatin in early-stage non-small-cell lung cancer: Southwest oncology group trial S9900, an intergroup, randomized, phase III trial. J Clin Oncol. 2010;28:1843-9.

5. Scagliotti GV, Pastorino U, Vansteenkiste JF, Spaggiari L, Facciolo F, Orlowski TM, et al. Randomized phase III study of surgery alone or surgery plus preoperative cisplatin and gemcitabine in stages IB to IIIA non-small-cell lung cancer. J Clin Oncol. 2012;30:172-8.

6. Filippatos GS, de Graeff P, Bax JJ, Borg JJ, Cleland JG, Dargie HJ, et al. Independent academic data monitoring committees for clinical trials in cardiovascular and cardiometabolic diseases. Eur J Heart Fail. 2017;19: 449-56.

7. Jackson N, Atar D, Borentain M, Breithardt G, van Eickels M, Endres M, et al. Improving clinical trials for cardiovascular diseases: a position paper from the cardiovascular round table of the European Society of Cardiology. Eur Heart J. 2016;37:747-54.

8. Pokharel Y, Tang F, Jones PG, Nambi V, Bittner VA, Hira RS, et al. Adoption of the 2013 American College of Cardiology/American Heart Association cholesterol management guideline in cardiology practices nationwide. JAMA Cardiol. 2017;2:361-9.

9. Pencina MJ, Navar-Boggan AM, D’Agostino RB Sr, Williams K, Neely B, Sniderman AD, et al. Application of new cholesterol guidelines to a population-based sample. N Engl J Med. 2014;370:1422-31.

10. Mack MJ, Acker MA, Gelijns AC, Overbey JR, Parides MK, Browndyke JN, et al; Cardiothoracic Surgical Trials Network (CTSN). Effect of cerebral embolic protection devices on CNS infarction in surgical aortic valve replacement: a randomized clinical trial. JAMA. 2017;318:536-47.

11. US National Commission for the Protection of Human Subjects of Biological and Behavioral Research. The Belmont Report: Ethical Principles and Guidelines for the Protection of Human Subjects of Research. Department of Health, Education, and Welfare (DHEW) Publication No. (OS) 78-0012, Appendix I, DHEW Publication No. (OS) 78-0013, Appendix II, DHEW Publication No. (OS) 78-0014. Washington, DC: US Government Printing Office; 1978.

12. Institute of Medicine (US). Committee on standards for developing trustworthy clinical practice guidelines. In: Graham R, Mancher M, Wolman DM, Greenfield S, Steinberg E, eds. Clinical Practice Guidelines We Can Trust. Washington, DC: National Academies Press; 2011. 